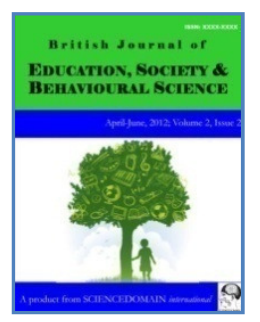

British Journal of Education, Society \& Behavioural Science

4(8): 1038-1057, 2014

SCIENCEDOMAIN international

www.sciencedomain.org

\title{
Reading Comprehension Instruction Practices in Sierra Leone
}

\author{
Stephanie Hersbach ${ }^{1}$, Eddie Denessen ${ }^{1}$ and Mienke Droop ${ }^{{ }^{*}}$ \\ ${ }^{1}$ Radboud University Nijmegen, Behavioural Science Institute, PO Box 9104, 6500 HE \\ Nijmegen, The Netherlands. \\ Authors' contributions
}

This work was carried out in collaboration between all authors. Authors SH and ED designed the study. Author SH collected the data in Sierra Leone and performed the analysis. Authors

$S H, E D$ and MD wrote the manuscript. All authors read and approved the final manuscript.

Original Research Article

Received $11^{\text {th }}$ February 2014

Accepted $29^{\text {th }}$ March 2014

Published $7^{\text {th }}$ April 2014

\section{ABSTRACT}

Aim: In this study an attempt was made to give insight in the way reading comprehension is taught in Sierra Leone. Attention was paid to the didactical strategies and the materials used during reading comprehension instruction.

Methodology: Primary school teachers in Sierra Leone $(\mathrm{N}=43)$ were observed while teaching reading comprehension. The teachers were also interviewed and filled in a questionnaire.

Results and Conclusion: Primary school teachers in Sierra Leone highly value the importance of reading comprehension. A teacher-centered learning style was the most dominant way of teaching, characterized by a whole-class organization and the teacher giving frontal instruction. This instruction focused mainly on pronunciation, learning new vocabularies and memorization and to a much lesser extent on reading strategies, such as summarizing and identification of the main idea of a text. The instruction is influenced by a lack of resources such as textbooks and reading materials.

Keywords: Reading comprehension instruction; developing countries; Sierra Leone.

*Corresponding author: Email: m.droop@pwo.ru.nl; 


\section{INTRODUCTION}

Poverty, inequality between boys and girls, bad maternal health and a high child mortality rate are some of the challenges developing countries face nowadays [1]. The aim of the Millennium Development Goals (MDGs) is to tackle these problems by the end of 2015. Education is of great importance when it comes to achieving the MDGs. Not only because two of the eight MDGs focus on education, namely to achieve universal primary education and to achieve gender equality in all levels of education, but also because education is of great importance when it comes to improving health [2] and decreasing child mortality [3]. Also, providing education leads to higher individual earnings [2] and is an investment in tackling poverty [4]. Therefore, raising the levels of schooling of the population has become a central part in many development strategies [5].

Among these development strategies with a strong focus on education are the Education For All (EFA) goals. These goals focus on both improving access to education and on improving the quality of education [3]. The importance of high quality education is also stressed in the 2005 EFA Global Monitoring Report [6] which points to the significance of providing conditions for all students to actually learn and develop skills and knowledge. In this report, it is stated that reading is a core subject for the improvement of quality of basic education, because it is the key for mastering other subjects. Furthermore, the National Reading Panel [7] states that reading comprehension is essential for obtaining an education, since reading is the foundation for future academic learning, as well as the basis for life-long learning activities. The final goal of reading comprehension instruction is for students to be able to independently read and comprehend different types of text for different purposes [8].

In teaching reading comprehension, the teacher has a great influence on the success rate of students in acquiring reading comprehension skills [9]. The quality of the reading comprehension instruction determines the ability of the students to become good readers who understand different types of text [8]. Didactical strategies of the teacher and the available resources and reading materials determine the quality of reading comprehension instruction. The past decades, learner-centered approaches (e.g., cooperative learning, individualized adaptive instruction) are being promoted as being more effective in reaching the goals of education than teacher-centered approaches (e.g., lecturing, frontal whole class instruction).

The aim of this study is to shed light on the practices regarding reading comprehension instruction in developing countries in order to improve the quality of reading education. The study was conducted in Sierra Leone. The focus of this study is on the processes in the classroom during reading comprehension instruction and on the way teachers shape the learning environment. An attempt is made to provide a detailed description of didactical strategies and resources the teachers use to teach reading comprehension. Therefore, the central research question of this study is: What does reading comprehension instruction in Sierra Leone look like?

Two sub questions are formulated: Which activities and didactical strategies do teachers engage in while instructing reading comprehension? What resources for reading comprehension instruction are available?

Developing countries face many challenges when it comes to providing high quality education. First of all, a large proportion of the teachers in developing countries does not have the proper qualifications needed for becoming a primary school teacher [6]. Also, many 
teachers do not sufficiently master the curriculum. Furthermore, the absenteeism among teachers is high [10]. Research done by Chaudhury and colleagues [11] showed that, on average, $19 \%$ of teachers were absent when unannounced visits were made to primary schools. Furthermore, many teachers were not working while present at the primary school. As a result of the expansion of student enrollment rates, the pupil-teacher ratio in developing countries is high: one teacher for every 60 students [6].

Another characteristic of education in developing countries is the language in which the students are taught. Many developing countries were former colonies and the official language spoken in colonial times has become the national language of the country. This language is also the language of instruction in schools and for many students this is not their mother tongue [10]. Since the development of students' mother tongue facilitates second language learning through transfer of knowledge and skills across languages, discouraging the development of the mother tongue has implications for the level of development of the second language [12]. Also, when teachers do not allow students to speak their mother tongue during class, they communicate a message that the students have to give up their mother tongue in order to be accepted by the teacher and the society. This could possibly lead to students who are less confident during classroom instruction [12].

Williams [13] studied reading instruction in Malawi in the nineties. He observed a common pattern in classrooms. Lessons were structured in a highly similar way with

(1) The teacher writing words from the text on the blackboard, reading them aloud, and the students repeating the words,

(2) The teacher reading the text sentence by sentence and the students repeat individually or in groups,

(3) The teacher asking questions, following the sequence of the text and the students answer individually after which the group repeats the answer.

Nowadays, in many developing countries, such as Tanzania, Botswana, South-Africa and Namibia, a shift is noticeable from a teacher-centered teaching style towards a learner-centered teaching style $[14,15]$. This is partly due to international aid agencies prescribing a learner-centered pedagogy through the educational projects they are funding. These agencies stress the importance of a learner-centered teaching style since this is seen as a democratic way of teaching, which involves dialogue between the teacher and the students $[15,16]$. This may lead to a change in the prevailing hierarchical social relations in the classroom: the teacher-centered teaching style involves an authoritarian teacher and more passive students [17] whereas a learner-centered teaching style focuses on an active role of students, with the teacher being a facilitator of the learning process [15] and more cooperation and discussion among students about their work. This change from a teacher-centered teaching style towards a learnercentered teaching style is hard to establish, since the hierarchical relationship between the teacher and the student is culturally accepted in many countries [18]. Croft [16] noticed a learner-centered teaching style more often found in lower grades, but not in higher grades.

In many developing countries, rote learning is a commonly used teaching technique $[10,13,19]$. Teachers who use rote learning as a teaching technique focus their instruction on memorizing, whereas less attention is paid to the actual meaning of what is learned. The curricula are often abstract, decontextualized and fact-centered. 
The quality of reading comprehension instruction and education in general, is likely to be influenced by the resources, such as textbooks and learning materials [6]. In many developing countries, these resources are lacking, as well as basic equipment, such as benches, desks and blackboards [10,20]. When textbooks and teaching materials are available, these are often outdated [21]. Also, schools do not have enough funding to pay for overhead costs, such as electricity or water. Even though some governments made promises to provide the communities with the necessary educational infrastructure, this did not always lead to actual changes, either because of misusing the money or because of the schools themselves falling short [22].

In the present study, practices regarding reading comprehension instruction in primary schools in Sierra Leone have been studied. In this country, located in the west of Africa, many people live below the poverty line and the country has one of the lowest rates of Africa on the Human Development Index [17]. In 2011 the literacy rate among adults was $43 \%$ [23]. After a recent civil war, the country was left with a disrupted educational sector [20]. The devastating effects on the educational sector are, among others, shortage of teaching materials, delay in paying teachers' salaries, displacement of teachers and overcrowded classrooms. English is the official language and, in spite of the thirteen different languages that are spoken in Sierra Leone, also the language of instruction in schools $[17,20]$.

The study focused on the didactical strategies of the teachers and the resources available for reading comprehension instruction. We focused on teaching style, student activities and the educational infrastructure (the available resources). The results of this study will contribute to the knowledge about the actual practices of reading comprehension instruction in developing countries and may support NGO's working in this field, as well as policymakers to focus their policies on the most striking areas for improvement which in turn will, hopefully, lead to an improvement of the quality of reading comprehension instruction in developing countries.

\section{METHODOLOGY}

Two studies were performed, a questionnaire study and an observation and interview study. The data were collected in October and November 2011. After each observation, the teacher was interviewed and a questionnaire was handed out to the teacher. Because of the length of the questionnaire, the questionnaires were collected a few days later. Because the questionnaires were anonymous and were collected from the school administration, they could not be linked to the corresponding observations and interviews.

Since some teachers who participated in the observation and interview study did not complete the questionnaire and some teachers filled in a questionnaire who did not participate in the observation and interview study, the numbers of participating teachers varies depending on the type of data. In total, 41 teachers participated in the questionnaire study and 43 teachers participated in the observation and interview study. The teachers were all teaching in schools located in urban areas, mostly in and around Freetown, the country's capital. The schools were selected by the Evangelical Fellowship of Sierra Leone (EFSL). This organization has a membership of different churches in Sierra Leone [24] and different Christian schools are linked to these churches.

Of the 41 teachers participating in the questionnaire study, 25 were male and 16 were female ${ }^{1}$. Most teachers were between 30 and 39 years old $(34.1 \%)$ and the mean number of

\footnotetext{
${ }^{1}$ No record was made of the gender and age of the teachers participating in the observation and interview study.
} 
years of teaching experience was 14.8 years $(S D=10.22)$. The teachers were teaching in year $3(18.6 \%)$, year $4(32.6 \%)$, year $5(25.6 \%)$ or year $6(23.3 \%)$ and all of them worked fulltime. Almost $85 \%$ of the teachers was certified to teach and had obtained an undergraduate degree. The numbers of students ranged from 17 to 95 per class with a mean class size of 40.33 students $(S D=16.51)$.

For reading comprehension, a formally-designed teaching syllabus is provided for the primary schools by the government of Sierra Leone. This syllabus includes objectives for a given period, suggested learning materials meant to reach these objectives and the teaching aids that can be used, mainly the textbooks provided by the government. A second syllabus is provided which gives an overview of the units and exercises that need to be covered in the lessons during a given week. The government also provides an exemplary timetable which includes four hours and 30 minutes of reading comprehension instruction per week (including literature). This time is divided over five lessons: four lessons of one hour and one lesson of 30 minutes. $90 \%$ of the teachers participating in the present study taught reading comprehension at least three times a week.

Three types of data were collected to document reading comprehension practices: observations, semi-structured interviews and a questionnaire. Observations were carried out to gain insight in the processes taking place in the classroom during reading comprehension instruction. Semi structured interviews with the teachers followed these observations. These interviews were meant to give insight in the reasons why the teachers shaped the learning environment the way they did. A questionnaire was developed to gain a more general insight in the way reading comprehension is taught, since the observations were a snapshot of what was happening during reading comprehension instruction. The questionnaires were aimed to provide more information about the frequency of the activities in the classroom.

An observation record was developed based on questionnaires used in PIRLS [25] and based on an observational study conducted by Van Elsäcker [26]. The following topics were included in the observation form: (a) organization of the classroom, (b) activities in the classroom, (c) activities during instruction, (d) focus of instruction, (e) activities after reading, and (f) materials used during the reading comprehension lesson and the types of text that were read.

1. Organization of the classroom. Three categories were distinguished: whole class organization, small group organization and individual organization. A 'whole class organization' was observed when all students were participating in the same activity. A 'small group organization' was observed when the students were sitting in groups and were collaborating with each other. An 'individual organization' was observed when all students worked separately on an assignment.

2. Activities in the classroom. Categories were 'teacher reads out loud', 'student reads out loud', 'student reads silently', 'teacher gives instruction', 'procedures', 'working on an assignment', and 'correcting behavior' as the possible activities. The activity 'student reads out loud' meant that either the whole class read out loud, one student read out loud to the whole class or a small group of students read out loud to the rest of the class. When 'procedures' was observed, an activity having no direct link to the content of the lesson, for example organizing tables or handing out books, was observed.

3. Activities during instruction. The following activities were included: 'oral instruction', 'oral questions', 'teacher writing on the blackboard', and 'student writing on the 
blackboard'. When the teacher was explaining what the passage was about, this meant 'oral instruction' was observed.

4. Focus of instruction. Based on Van Elsäcker [26] the following categories were included: 'prior knowledge,' 'word/sentence meaning', 'paragraph/ text meaning', 'illustrations/graphs', 'reading strategies', 'decoding sounds and words', and 'giving instruction about the assignment'.

5. Activities after reading. Categories included were: 'written response', 'discussion', 'project', and 'test'. When 'written response' was observed, the teacher asked the students to write something in response to what was read or to answer written questions in their notebooks. When the students were asked to do a play or do an art project, a 'project' was observed.

6. Materials used during the reading comprehension lessons and the types of text that were read. Categories were 'textbooks', 'reading series', 'workbooks or worksheets', 'children's newspapers and magazines', 'computer software for reading instruction', 'reading materials on the internet', 'a variety of children's books', 'materials from other subjects', 'materials written by students', and 'other materials'. When the use of 'textbooks' was observed, the class was reading in a textbook designed for reading comprehension instruction containing short stories. 'Reading series' were children's books meant specifically for students reading at a certain reading level. 'A variety of children books' meant that the class was reading books written for recreational purposes. 'Other materials' were, for example, exams of previous years.

The observation included predominant activity sampling. During a time interval of 20 seconds the dominant activity or activities were recorded. Following Van Elsäcker [26], intervals of 10 seconds were used for observation. Each 10-second-interval was followed by another 10second-interval which was meant for registering the observed activity. Complete lessons were observed. Lesson duration varied with a mean lesson time of one hour (mean number of observed time intervals $M=202.09, S D=76.06$, $\min .=66$, $\max =365$ ).

The following topics were included in the first part of the observation: organization of the classroom, activities in the classroom, activities during instruction and activities after reading. The activity was registered when the majority of the students was involved in an activity at a particular moment. When multiple activities were observed as dominant activities during an interval, all activities were registered. For example, when the teacher was writing something on the blackboard while giving oral instruction, both 'teacher writing on the blackboard' and 'teacher giving oral instruction' were registered. This means the sum of the percentages of activities may exceed $100 \%$, since the presence of one activity did not rule out the other activities.

For the other topics, a checklist was used to code the focus of the instruction, materials used during the reading comprehension lesson and types of text used during the reading comprehension lesson. For each lesson it was observed whether a particular activity occurred. The data represent the percentages of the total number of reading comprehension lessons in which the activity occurred.

Post-observational interviews were held with the teachers to gain insight in the reasons why the teachers shaped the reading comprehension lessons the way they did, how they involved students who had difficulty in reading comprehension and the challenges they faced during the instruction of reading comprehension. The interviews were held after the classroom observations so that observations could be discussed in the interview. The interviews were semi-structured and were recorded with a recording device. 
The questionnaire was meant to provide a more general insight in the way reading comprehension is taught. The questionnaire was a shortened version of the PIRLS questionnaire. The questions pertained to the didactical strategies used and referred to the organization of the classroom, the activities in the classroom, the focus of instruction, the activities after reading, assigning reading as a part of homework, activities when a student falls behind and the way in which the teachers monitor the students' performance. An example item of each topic concerning the didactical strategies and the accompanying answering categories are presented in Table 1. Also, the available resources for reading comprehension instruction were questioned. Questions were asked about the reading materials, the availability of computers and the availability of a library (see Table 1).

Table 1. Variables, example items and answering categories for the part of the questionnaire concerning the didactical strategies and resources

\begin{tabular}{|c|c|c|}
\hline Variables & Example item & Answering categories \\
\hline \multicolumn{3}{|l|}{ Didactical strategies } \\
\hline Organization of the classroom & $\begin{array}{l}\text { I teach reading as a whole- } \\
\text { class activity }\end{array}$ & $\begin{array}{l}\text { (1) always or almost always } \\
\text { (2) often } \\
\text { (3) sometimes } \\
\text { (4) never }\end{array}$ \\
\hline Activities in the classroom & $\begin{array}{l}\text { How often do you read aloud } \\
\text { to the class? }\end{array}$ & $\begin{array}{l}\text { (1) every day or almost } \\
\text { every day } \\
\text { (2) once or twice a week } \\
\text { (3) once or twice a month } \\
\text { (4) never or almost never }\end{array}$ \\
\hline Focus of instruction & $\begin{array}{l}\text { How often do you ask the } \\
\text { students to identify the main } \\
\text { ideas of what they have read? }\end{array}$ & $\begin{array}{l}\text { (1) every day or almost } \\
\text { every day } \\
\text { (2) once or twice a week } \\
\text { (3) once or twice a month } \\
\text { (4) never or almost never }\end{array}$ \\
\hline Activities after reading & $\begin{array}{l}\text { How often do you ask the } \\
\text { students to write something } \\
\text { about or in response to what } \\
\text { they have read? }\end{array}$ & $\begin{array}{l}\text { (1) every day or almost } \\
\text { every day } \\
\text { (2) once or twice a week } \\
\text { (3) once or twice a month } \\
\text { (4) never or almost never }\end{array}$ \\
\hline $\begin{array}{l}\text { Assigning reading as a part of } \\
\text { homework }\end{array}$ & $\begin{array}{l}\text { How often do you assign } \\
\text { reading as a part of homework } \\
\text { (for any subject)? }\end{array}$ & $\begin{array}{l}\text { (1) I do not assign reading } \\
\text { for homework } \\
\text { (2) less than once a week } \\
\text { (3) one or two times a week } \\
\text { (4) three or four times a } \\
\text { week } \\
\text { (5) every day }\end{array}$ \\
\hline $\begin{array}{l}\text { Activities when a student falls } \\
\text { behind }\end{array}$ & $\begin{array}{l}\text { Do you usually wait to see if } \\
\text { performance improves with } \\
\text { maturation when a student } \\
\text { falls behind? }\end{array}$ & $\begin{array}{l}\text { (1) yes } \\
\text { (2) no }\end{array}$ \\
\hline $\begin{array}{l}\text { The way in which the } \\
\text { teachers monitor the } \\
\text { students' performance }\end{array}$ & $\begin{array}{l}\text { How often do you use } \\
\text { multiple-choice questions on } \\
\text { materials read to assess } \\
\text { students' performance in } \\
\text { reading? }\end{array}$ & $\begin{array}{l}\text { (1) every day or almost } \\
\text { every day } \\
\text { (2) once or twice a week } \\
\text { (3) once or twice a month } \\
\text { (4) never or almost never }\end{array}$ \\
\hline
\end{tabular}


Table 1 Continued.....

\begin{tabular}{|c|c|c|}
\hline \multicolumn{3}{|c|}{ Resources for reading comprehension instruction } \\
\hline $\begin{array}{l}\text { Materials being used during } \\
\text { reading comprehension } \\
\text { instruction }\end{array}$ & $\begin{array}{l}\text { When you have reading } \\
\text { instruction and/or do reading } \\
\text { activities with the students, } \\
\text { how often do you use } \\
\text { textbooks? }\end{array}$ & $\begin{array}{l}\text { (1) every day or almost } \\
\text { every day } \\
\text { (2) once or twice a week } \\
\text { (3) once or twice a month } \\
\text { (4) never or almost never }\end{array}$ \\
\hline $\begin{array}{l}\text { The use of different types of } \\
\text { text }\end{array}$ & $\begin{array}{l}\text { When you have reading } \\
\text { instruction and/or do reading } \\
\text { activities with the students, } \\
\text { how often do you have the } \\
\text { students read poems? }\end{array}$ & $\begin{array}{l}\text { (1) every day or almost } \\
\text { every day } \\
\text { (2) once or twice a week } \\
\text { (3) once or twice a month } \\
\text { (4) never or almost never }\end{array}$ \\
\hline The availability of computers & $\begin{array}{l}\text { Are computers available for } \\
\text { use by your class? }\end{array}$ & $\begin{array}{l}\text { (1) yes } \\
\text { (2) no }\end{array}$ \\
\hline The availability of a library & $\begin{array}{l}\text { Do you have a library or } \\
\text { reading corner in your } \\
\text { classroom? }\end{array}$ & $\begin{array}{l}\text { (1) yes } \\
\text { (2) no }\end{array}$ \\
\hline
\end{tabular}

Because of the descriptive nature of this study a detailed description of reading comprehension instruction is provided by reporting means, standard deviations and percentages for each observation category and questionnaire item. The interviews were transcribed and summarized according to the reading comprehension instruction topics.

\section{RESULTS}

In this section we first present the descriptive quantitative observation and questionnaire data. In the second part of the results section, we present the qualitative interview data.

\subsection{Results of the Observation and Questionnaires Regarding Reading Comprehension Practices in Sierra Leone}

\subsubsection{Organization of the classroom}

\subsubsection{Observations}

The most common classroom organization was a whole class organization $(M=75.3 \%$ of the time, $S D=18.62$ ). Less common was an individual classroom organization with the students working individually on an assignment $(M=26.7 \%, S D=20.05)$. Activities done in small groups were observed $0.1 \%$ of the time $(S D=0.21)$.

\subsubsection{Questionnaires}

$78 \%$ of the teachers stated to always or almost always teach reading as a whole class activity; $40 \%$ used an individual organization always or almost always. $32.5 \%$ of the teachers let the students frequently work independently on an assigned plan or goal and $12.5 \%$ of the teachers stated to frequently let the students work independently on a goal they choose themselves. With respect to ability grouping, $37.5 \%$ of the teachers reported that they always or almost always create mixed-ability groups and $15.4 \%$ of the teachers said they always or almost always create same-ability groups. Table 2 gives a complete overview of the frequencies of classroom organization. 
It should be noted that there was a discrepancy between the observations and the questionnaires for working in groups. The questionnaire revealed a much higher prevalence of group work than the actual observations. A possible explanation is that during the classroom observations it was noticed that the classroom was organized in groups, but they were still doing activities as a whole class.

Table 2. Frequency (in percentages) of the organization of the classroom during reading comprehension instruction, based on the questionnaires $(\mathrm{N}=41)$

\begin{tabular}{|c|c|c|c|c|}
\hline & $\begin{array}{l}\text { Always } \\
\text { or almost } \\
\text { always }\end{array}$ & Often & Sometimes & Never \\
\hline I teach reading as a whole-class activity & 78.0 & 17.1 & 4.9 & .0 \\
\hline I create same ability groups & 15.4 & 12.8 & 59.0 & 12.8 \\
\hline I create mixed-ability groups & 37.5 & 15.0 & 47.5 & .0 \\
\hline I use individualized instruction for reading & 40.0 & 5.0 & 45.0 & 10.0 \\
\hline $\begin{array}{l}\text { Students work independently on an } \\
\text { assigned plan or goal }\end{array}$ & 32.5 & 20.0 & 42.5 & 5.0 \\
\hline $\begin{array}{l}\text { Students work independently on a goal they } \\
\text { choose themselves }\end{array}$ & 12.5 & 20.0 & 37.5 & 30.0 \\
\hline
\end{tabular}

\subsubsection{Activities in the classroom}

\subsubsection{Observations}

On average, teachers were observed giving instruction over $50 \%$ of the total lesson time $(M$ $=50.29 .7 \%, S D=18.26)$. Other frequently observed activities were students working on an assignment $(M=26.7 \%, S D=20.56)$, teachers reading aloud $(M=10.6 \%, S D=8.01)$ and students reading aloud $(M=19 \%, S D=12.82)$. Students reading silently was not a common activity $(M=.04 \%, S D=.25))$. Procedures and correcting behavior took up a small portion of the time $(M=6 \%, S D=4.92$, and $M=1.6 \%, S D=1.73$, respectively).

\subsubsection{Questionnaires}

$82.5 \%$ of the teachers reported to read aloud to the class every day or almost every day. Other frequent activities were asking the students to read aloud to the whole class $(80 \%$ of the teachers) and asking the students to read aloud in small groups or pairs $(60 \%$ of the teachers). Less frequent activities were asking the students to read silently, asking students to read along silently while other students read aloud, and giving the students time to read in self chosen books (see Table 3).

\subsubsection{Activities during reading comprehension instruction}

\subsubsection{Observations}

When teachers were instructing, the most frequently observed activities were the teacher writing on the blackboard, $(M=45.3, S D=7.74)$ giving oral instruction and questioning $(M=$ 24.35, $S D=12.19$, and $M=19.51, S D=12.07$, respectively). In 22.4 percent of the observed instruction time, it was observed that students were writing on the blackboard $(M=$ 22.4, $S D=5.05)$. 
Table 3. Frequency of activities (in percentages) during reading comprehension instruction, focus on strategies, activities after reading and assessment practices based on the questionnaires $(\mathrm{N}=37)$

\begin{tabular}{|c|c|c|c|c|}
\hline & $\begin{array}{l}\text { Every day or } \\
\text { almost every } \\
\text { day }\end{array}$ & $\begin{array}{l}\text { Once or } \\
\text { twice a } \\
\text { week }\end{array}$ & $\begin{array}{l}\text { Once or } \\
\text { twice a } \\
\text { month }\end{array}$ & $\begin{array}{l}\text { Never or } \\
\text { almost } \\
\text { never }\end{array}$ \\
\hline \multicolumn{5}{|l|}{$\begin{array}{l}\text { Activities during reading } \\
\text { comprehension instruction }\end{array}$} \\
\hline Read aloud to the class & 82.5 & 15.0 & 2.5 & .0 \\
\hline $\begin{array}{l}\text { Ask students to read aloud to the } \\
\text { whole class (groups and individual) }\end{array}$ & 80.0 & 17.5 & 2.5 & .0 \\
\hline $\begin{array}{l}\text { Ask students to read aloud in small } \\
\text { groups or pairs }\end{array}$ & 60.0 & 35.0 & 2.5 & 2.5 \\
\hline $\begin{array}{l}\text { Ask students to read silently on their } \\
\text { own }\end{array}$ & 16.7 & 38.9 & 27.8 & 16.7 \\
\hline $\begin{array}{l}\text { Ask students to read along silently } \\
\text { while other students read aloud }\end{array}$ & 13.5 & 10.8 & 2.7 & 73.0 \\
\hline $\begin{array}{l}\text { Give students time to read books of } \\
\text { their own choosing }\end{array}$ & 13.5 & 13.5 & 45.9 & 27.0 \\
\hline $\begin{array}{l}\text { Teach or model for students different } \\
\text { reading strategies }\end{array}$ & 37.8 & 24.3 & 16.2 & 21.6 \\
\hline $\begin{array}{l}\text { Teach students strategies for } \\
\text { decoding sounds and words }\end{array}$ & 45.7 & 34.3 & 5.7 & 14.3 \\
\hline $\begin{array}{l}\text { Teach students new vocabulary } \\
\text { systematically }\end{array}$ & 78.4 & 13.5 & 8.1 & .0 \\
\hline $\begin{array}{l}\text { Help students understand new } \\
\text { vocabulary in texts they are reading }\end{array}$ & 68.4 & 28.9 & .0 & 2.6 \\
\hline \multicolumn{5}{|l|}{ Strategies } \\
\hline $\begin{array}{l}\text { Identify the main ideas of what they } \\
\text { have read }\end{array}$ & 82.5 & 15.0 & 2.5 & .0 \\
\hline $\begin{array}{l}\text { Explain or support their understanding } \\
\text { of what they have read }\end{array}$ & 82.1 & 15.4 & 2.6 & .0 \\
\hline $\begin{array}{l}\text { Compare what they have read with } \\
\text { experiences they have had }\end{array}$ & 65.0 & 17.5 & 15.0 & 2.5 \\
\hline $\begin{array}{l}\text { Compare what they have read with } \\
\text { other things they have read }\end{array}$ & 42.1 & 39.5 & 18.4 & .0 \\
\hline $\begin{array}{l}\text { Make predictions about what will } \\
\text { happen next in the text they are } \\
\text { reading }\end{array}$ & 20,5 & 48.7 & 12.8 & 17.9 \\
\hline $\begin{array}{l}\text { Make generalizations and draw } \\
\text { interferences based on what they } \\
\text { have read }\end{array}$ & 56.4 & 12.8 & 17.9 & 12.8 \\
\hline $\begin{array}{l}\text { Describe the style or structure of the } \\
\text { text they have read }\end{array}$ & 51.3 & 20.5 & 17.9 & 10.3 \\
\hline \multicolumn{5}{|l|}{ Activities after reading } \\
\hline $\begin{array}{l}\text { Answer reading comprehension } \\
\text { questions in a workbook or on a } \\
\text { worksheet about what they have read }\end{array}$ & 76.9 & 20.5 & 2.6 & .0 \\
\hline $\begin{array}{l}\text { Write something about or in response } \\
\text { to what they have read }\end{array}$ & 56.8 & 24.3 & 13.5 & 5.4 \\
\hline
\end{tabular}


Table 3 Continued........

\begin{tabular}{|c|c|c|c|c|}
\hline $\begin{array}{l}\text { Answer oral questions about or orally } \\
\text { summarize what they have read }\end{array}$ & 74.4 & 20.5 & 5.1 & .0 \\
\hline $\begin{array}{l}\text { Talk with each other about what they } \\
\text { have read }\end{array}$ & 44.7 & 39.5 & 15.8 & .0 \\
\hline $\begin{array}{l}\text { Do a project about what they have } \\
\text { read (e.g., a play or art project) }\end{array}$ & 5.4 & 29.7 & 48.6 & 16.2 \\
\hline $\begin{array}{l}\text { Take a written quiz or test about what } \\
\text { they have read }\end{array}$ & 7.7 & 35.9 & 51.3 & 5.1 \\
\hline \multicolumn{5}{|l|}{ Assessment of reading } \\
\hline $\begin{array}{l}\text { Multiple-choice questions on materials } \\
\text { read }\end{array}$ & 55.3 & 31.6 & 7.9 & 5.3 \\
\hline $\begin{array}{l}\text { Short-answer written questions on } \\
\text { materials read }\end{array}$ & 51.3 & 43.6 & 5.1 & .0 \\
\hline $\begin{array}{l}\text { Paragraph-length written responses } \\
\text { about what students have read }\end{array}$ & 24.3 & 48.6 & 18.9 & 8.1 \\
\hline Listening to students read aloud & 76.9 & 10.3 & 12.8 & .0 \\
\hline Oral questioning of students & 78.9 & 18.4 & 2.6 & .0 \\
\hline $\begin{array}{l}\text { Students give an oral summary/report } \\
\text { of what they have read }\end{array}$ & 51.3 & 38.5 & 7.7 & 2.6 \\
\hline $\begin{array}{l}\text { Meeting with students to discuss what } \\
\text { they have been reading and work they } \\
\text { have done }\end{array}$ & 20.5 & 48.7 & 30.8 & .0 \\
\hline
\end{tabular}

\subsubsection{Focus of instruction}

\subsubsection{Observations}

The data from the observation checklist revealed that $53.5 \%$ of the 43 teachers paid attention to the meaning of the text or paragraph. $51.2 \%$ of the teachers focused their instruction on the meaning of a word or sentence. $88.4 \%$ of the teachers gave instruction about the assignment the students had to do. Less attention was paid to reading strategies $(7.0 \%)$, indicating little attention was paid to explaining the students about what strategies they could use to get the main idea of the text or to find an answer to the questions. Also, little attention was paid to decoding sounds and words (9.3\%). The teachers did not focus their instruction on breaking down difficult words. Furthermore, about a quarter of the teachers focused their instruction on prior knowledge (25.6\%) and illustrations and graphs $(27.9 \%)$.

\subsubsection{Questionnaires}

Almost all teachers reported to put emphasis on teaching new vocabulary once a week, either through the explicit teaching of new vocabulary $(91.9 \%)$ or through helping students understand vocabulary in the texts they were reading (97.4\%). For reading comprehension, the teachers reported to pay most attention to the identification of the main ideas and explaining or supporting the students' understanding of what they had read. The teachers further stated they made comparisons frequently, at least once a week, through comparing what the students had read with experiences they had (82.5\%) and with other things they had read $(81.6 \%)$. Less frequent were making predictions about what will happen next in the text $(69.2 \%)$, as well as describing the style or structure of the text $(71.8 \%)$. Also, $69.2 \%$ of the teachers said to be making generalizations and drawing inferences (see Table 3). 


\subsubsection{Activities after reading}

\subsubsection{Observations}

After reading a passage, almost $80 \%$ of the teachers instructed the students to work on an individual assignment. In most cases this meant that the students had to copy the passage, the key words or the questions and answers from the blackboard. In some cases the students had to make sentences with these key words. The mean percentage of the lesson time the students spent on an individual assignment was $26.2 \%(S D=20.14)$.

\subsubsection{Questionnaires}

The most common activities after reading were answering reading comprehension questions. $76.9 \%$ of the teachers reported to ask the students to answer written questions every day or almost every day and $74.4 \%$ of the teachers said to instruct the students to answer oral questions or orally summarize what they had read every day or almost every day. Less common activities were doing a project, such as a play or an art project about what they had read $(64.8 \%$ of the teachers asked the students to do this not more than twice a month) or taking a written quiz or test about what they had read $(56.4 \%$ of the teachers asked the students to do this no more than twice a month). The teachers reported that the most frequently used methods for assessing the students' performance were asking oral questions (78.9\% of the teacher did this every day or almost every day) and listening to students reading aloud (76.9\%). Other frequently used methods were multiple-choice questions $(55.3 \%)$, short-answer written questions on materials read $(51.3 \%)$ and listening to students giving an oral summary or oral report of what they had read (51.3\%). Less frequent ways assessments were paragraph-length written responses (24.3\%) and meeting with students to discuss what they have been reading $(20.5 \%$, see Table 3$)$.

The most common activities the teachers engaged in to support struggling readers were assigning homework and asking the parents to help the student $(100 \%$ of the teachers reported to do this) and spending more time working individually with those students (83.8\% of the teachers reported to do this). Also, $75 \%$ of the teachers reported to ask other students to help the students having difficulty. These results are presented in Table 4.

Table 4. Percentage of the teachers engaging in activities for struggling readers, based on the questionnaires $(\mathrm{N}=35)$

\begin{tabular}{lc}
\hline I wait to see if performance improves with maturation & 40.0 \\
I spend more time working on reading individually with that student & 83.8 \\
I have other students work on reading with the student having difficulty & 75.0 \\
I have the student work in the regular classroom with a teacher-aide & 58.3 \\
I have the student work in the regular classroom with a reading specialist & 28.6 \\
I have the student work in a remedial reading classroom with a reading specialist & 37.1 \\
I assign homework to help the student catch up & 100.0 \\
I ask the parents to help the student with reading & 100.0 \\
\hline
\end{tabular}




\subsubsection{Reading materials}

\subsubsection{Observations}

The teachers mostly used textbooks with worksheets (79.1\%). These textbooks contained short passages along with questions. However, in many classes there were only few textbooks available and the students had to share the textbooks, varying from one textbook for every two students to no textbook at all for the students. Other materials used during reading comprehension instruction were children's books (16.3\%). These books contained longer stories with chapters, but did not contain questions about the story. Further, materials from other subjects $(2.3 \%)$ and exams of previous years $(2.3 \%)$ were used in some classes. Reading materials like children's newspapers, or magazines, materials written by students, computer software, or materials from internet were not observed.

\subsubsection{Questionnaires}

In the questionnaires, $73.2 \%$ of the teachers reported to use textbooks every day or almost every day and $41 \%$ of the teachers reported to use materials from other subjects every day or almost every day. Other commonly used materials (every day or almost every day) were reading series $(24.3 \%)$ and workbooks or worksheets $(31.6 \%)$. Also, the questionnaires revealed that more than $50 \%$ of the teachers used the same materials with students at different reading levels by either letting them work at a different speed $(22 \%)$ or have them work at the same speed (36.6\%). The complete results of the materials used as reported in the questionnaires are presented in Table 5.

\subsubsection{Availability of a library}

Almost $32 \%$ of the teachers stated to have a library or reading corner in their classroom. The number of books varied greatly in these libraries or reading corners, ranging from 4 to 300 books, with a mean number of books of $72(S D=94.02)$. Also, the number of magazines varied greatly, ranging from none to 130 , with the mean number of magazines being 41 ( $S D$ $=59,31)$. When there was a library or reading corner available, the students were allowed to use these facilities frequently ( $57.1 \%$ of the classes could use these once or twice a week). $50 \%$ of the teachers who had a library or reading corner in their classroom allowed the students to borrow books and take them home. Only $21.6 \%$ of the teachers sometimes sent their students to a library other than their classroom library, but this was not very frequent (once or twice a month).

\subsubsection{Availability of computers}

Most teachers did not have the availability of computers in their school: only $7.7 \%$ of the teachers had computers available for their class. Of the available computers, $66.7 \%$ had access to the Internet. The computers were used by the students to search information on the internet, to write stories or other texts and to use instructional software to exercise reading skills. 
Table 5. Frequency of the use of different materials and different type of texts by teachers (in percentages), based on the questionnaires $(\mathrm{N}=38)$

\begin{tabular}{lllll}
\hline & $\begin{array}{l}\text { Every day } \\
\text { or almost } \\
\text { every day }\end{array}$ & $\begin{array}{l}\text { Once or } \\
\text { twice a } \\
\text { week }\end{array}$ & $\begin{array}{l}\text { Once or } \\
\text { twice a } \\
\text { month }\end{array}$ & $\begin{array}{l}\text { Never or } \\
\text { almost } \\
\text { never }\end{array}$ \\
\hline Different materials & & & & \\
\hline Textbooks & 73.2 & 22.0 & 4.9 & .0 \\
$\begin{array}{l}\text { Reading series (basal readers, graded } \\
\text { readers) }\end{array}$ & 24.3 & 43.2 & 18.9 & 13.5 \\
$\begin{array}{l}\text { Workbooks or worksheets } \\
\text { Children's newspapers and/or magazines }\end{array}$ & 31.6 & 23.7 & 10.5 & 34.2 \\
Computer software (CD, DVD) & .0 & 10.5 & 15.8 & 71.1 \\
$\begin{array}{l}\text { Reading materials on the Internet } \\
\text { A variety of children's books }\end{array}$ & 2.6 & .0 & 2.7 & 97.3 \\
Materials from other subjects & 10.3 & 28.2 & 3.1 & 92.3 \\
Materials written by students & 41.0 & 41.0 & 12.8 & 28.2 \\
\hline Different types of texts & 17.9 & 15.4 & 12.8 & 53.8 \\
\hline $\begin{array}{l}\text { Short stories } \\
\text { Longer books with chapters (fiction) }\end{array}$ & 24.4 & 53.7 & 12.2 & 9.8 \\
$\begin{array}{l}\text { Poems } \\
\text { Plays }\end{array}$ & 15.0 & 51.3 & 10.3 & 35.9 \\
$\begin{array}{l}\text { Descriptions and explanations about } \\
\text { things, people, or events (non-fiction) }\end{array}$ & 5.3 & 50.0 & 17.5 & 17.5 \\
Instructions or manuals about how things & 13.2 & 26.3 & 50.0 & 18.4 \\
work & & 28.9 & 26.3 & 5.3 \\
Charts, diagrams, graphs & 28.2 & 39.5 & 31.6 & 15.8 \\
\hline
\end{tabular}

\subsection{Results of the Interviews Regarding Reading Comprehension Practices in Sierra Leone}

In the interviews the teachers were asked about their perception of the quality of reading comprehension education in their school. The teachers were quite satisfied with the way they teach reading comprehension. First of all, the teachers found it important to put a lot of emphasis on pronunciation through repeating the passage and the words over and over again. They found this important because English is not the mother tongue of the students and they have difficulty pronouncing the words properly. The following quotations of participating teachers are illustrative:

'In our country, Krio is a more common language than English. Even at their homes they speak more Krio than English. We help them to speak good English. But what makes it so difficult? As soon as they get home, they speak Krio instead of English.'

'Because pronunciation is important. In Freetown, a child is not really acquainted with good pronunciation. If that child goes up to even university, it's not able to pronounce and speak properly. So it pays back even in higher education. That child has grown or developed that type of speech. It's very difficult now to correct it. That's why it's better to put things in place before it's too late.' 
Second, the teachers found it important for the students to have enough practice. They stated that the students should be exposed to different texts and they should make enough exercises. These exercises should start simple, but become more complex the more the students develop their reading comprehension skills. The teachers emphasized going down to the level of the students for them to fully understand. One teacher said:

'Children learn more if they can practice. I believe in giving a lot of exercises. Because then you can keep the students on their toes and that is better. Making exercises will keep them busy. According to some educational research, when you let them make exercises it sticks. The further you go, the exercises become a little bit more complex. You allow the children to think, so that it becomes a challenge for them.'

Finally, the teachers emphasized the importance of visualization, either by demonstrating what is happening in the passage or by looking at the pictures in the textbook. When the students are able to visualize what is read, it is thought that they will be better able to remember:

'Well, actually in teaching reading and comprehension, I would like to see that children come to the blackboard or to the front of the class and demonstrate. That activates their minds. Some of them are eager to come to the blackboard.'

\subsubsection{Involving students who have difficulty with reading comprehension}

The teachers acknowledged that there are slow learners and fast learners in their classes. Some teachers see it as their goal to get every student to understand the passage; others say it is impossible to get everyone on track. The following quotations show these different views:

'In every class we have the fast learners and we have the slow learners. It all depends on you, the teacher, how to deal with them. Because some children have understood what the teacher said, but for some children it takes a long time. So you, the teacher, don't mind whether the fast learners have understood. You try to do your best, your effort, over and over, for the slow learners, to let them understand. That's why they put them in school, to understand. It's all in the effort.'

'Out of 50 students if 25 students know the passage you know the message got through. But if out of 50 students only 5 students get it correct, automatically they don't understand. So you start again. So that they will know'.

Two common things for the teachers to do in order to check the students' comprehension were asking questions about the passage and letting the students reread individually:

'As they are reading, I listen to them to see who is already reading. Because when they are reading in groups, there are some who are just moving their mouths. They will hide in the voices of others. After they have read, I will select the ones who have just been moving their mouths, not doing anything. To really push them there'.

The teachers used different methods in order to help students to understand a passage. One frequently used method was repeating the passage over and over again. Some teachers emphasized the importance of first the teacher reading the passage and afterwards the 
students repeating what was read. Some teachers also found it important to discuss with the students what was read, so all the students would know what the passage was about:

'You will help them to understand the passage by asking them to read it again. And then they go paragraph by paragraph. Explain the first paragraph, let them tell what they have gathered, what they have grabbed out of that paragraph.'

Other methods the teachers used were giving the students homework so they can practice at home, talking to the parents or giving one to one instruction after class:

'Sometimes I conduct extra classes for them to try to and teach them how to read. In my own time, after class I ask them to stay about 30 minutes and then I teach them how to cope.'

\subsubsection{Challenges}

The teachers reported many challenges when it comes to instructing reading comprehension. These challenges are intertwined, but can be divided into three groups: challenges in the school, challenges concerning the home and challenges with the students themselves.

As for challenges in the school, the biggest problem all teachers encountered was the lack of materials. The available books had to be shared among the students and sometimes there was just one book available: the one for the teacher. Most teachers coped with this problem by grouping students and sharing books with the consequence that some students are not being able to see or read the text properly:

'So that's how we try to cope with by putting them in groups. They cannot read together, there are only a few who have a book and are being able to read properly. Those with the books upside down don't read properly. It's all about management.'

Another problem in the school was the lack of teaching accommodation, such as benches and tables for the students. Some teachers had difficulty with the small blackboards, because they were not able to write the whole passage on it. In addition, the teachers had to cope with very big classes and a lot of noise coming from the other classes. Some teachers also mentioned to have difficulties to do the whole instruction in the short timeframe arranged for reading comprehension.

The home challenges the teachers reported were the lack of support at home when the students were making their homework. Therefore, many students did not make their homework at all. Also, the teachers reported that the students did not have time to do their homework and sometimes were not even coming to school. In addition, some students did not get a proper breakfast because of financial constraints at the home. This leads to students being sick in class and having difficulty to pay attention:

'Other than that, some people who come from poor homes, they don't eat. They don't give their children breakfast. Because of the financial constraints. They just have one meal a day. You find them dull. Their attitude, when you stand in front of them, either they're sleeping or they're so dull. You can't ask them, when you ask them questions you find out some of them look sick. Well, in other countries, the first thing they do, is provide them breakfast. But this is Africa. Here they are poor.' 
As challenges concerning the students themselves, the teachers reported problems with motivating the students and bringing the students who have difficulty in reading comprehension on track. They also mentioned that learning the students to read in their second language is a big challenge. The students had difficulty pronouncing and understanding the words and sometimes used words from their mother tongue instead of the language of communication in the schools: English. Moreover, some students in the higher grades still lack the basic decoding skills:

'Some children are not competent with reading, they cannot read well. You see, some of our children did not start schooling from the first stage. They were accepted into this school from other schools. When the children don't do well in class, they are sent out of school. And so when they come to our school, we are sympathetic. They come to us at class 5 or class 6 . How can you manage now? You help them. So for those that came from other schools, it's difficult for them to learn to read. But those who started from the initial stage in our school they can get on well. There are a few of them coming from other schools. $50 \%$ can read and the others can't.'

\section{DISCUSSION}

The goal of the present study was to give insight in the way reading comprehension is taught in Sierra Leone. With respect to characteristics of instruction, the most common activity during the reading comprehension lessons was for the teacher to give instruction to the whole class. During this instruction, memorization of the passage by asking questions focused on recalling information was stimulated. The instruction was focused on the meaning of the passage and on learning new vocabulary. In all activities the teachers emphasized a proper pronunciation of words, because for most students English is not their mother tongue and they have difficulty pronouncing words in a right way. The teachers are convinced that a good pronunciation helps them in learning the second language. Not only the passage and the vocabularies were repeated frequently, but also the questions and answers were asked many times. The main reason for the teachers to do this was to keep the students who have difficulty in reading comprehension on track. This is a difficult task, because not all students were able to read or decode the text and the teachers have to deal with large differences in abilities. Therefore, a common activity while teaching reading comprehension was for the teacher to read aloud and the students having to repeat what was read. After this reading instruction, the most common activity the teachers asked the students to do was copying the passage, vocabulary and questions and answers from the blackboard into their notebooks so they could study them at home.

The present study confirms the literature discussed in the introduction. The structure of reading comprehension described by Williams [13] in his study on Malawian practices of reading instruction was also dominant in our observations and is characterized by a teachercentered teaching style, a whole class organization and a strong focus on copying and memorizing text. The teachers themselves were grown up in this tradition and in the interviews they highly valued the focus on pronunciation for learning English, copying of text and rote learning.

In many classrooms only limited resources were available. Students had to share textbooks in groups and often were not able to see the text properly. Due to the lack of materials, the copying of text also is a necessary means to give children access to the text. Nevertheless, the instruction also focused on the meaning of the text or paragraph, which means the teachers did not rely on rote learning only and some aspects of a learner-centered teacher 
style were also observed. The teachers were certainly aware of the importance of reading strategies such as providing and activating background knowledge and discussing the main idea of the text.

Since a teacher-centered teaching style still was found to be the dominant way of teaching and only some aspects of a learner-centered teaching style were present, one might argue that Sierra Leone finds itself at the beginning stage of a transition $[14,15]$. This transition could take a long time, since Sierra Leone recently suffered from a civil war which disrupted the educational system. Also, due to the recent civil war, Sierra Leone does not have a long tradition of foreign development programs focused on education, which means a more learner-centered teaching style has just been promoted recently.

Some methodological limitations were present in this study. First of all, the study was conducted among a small group of teachers and only one lesson of the teachers was observed. Only schools in an urban area participated. The generalizibility of the results to other schools and contexts can thus be questioned. Second, the observation and questionnaire data revealed different patterns. The observation data point to more traditional teacher-centered activities, whereas the questionnaires point to a more learner-centered teaching approach. This stresses the importance of the use of multiple instruments to gain a reliable and valid picture of the reading comprehension instruction.

Despite these limitations, the results of this study give directions for future policy and might help NGO's to decide on which aspects to focus when supporting teachers in their reading comprehension teaching in developing countries. A possible focus of a teacher training could be to lessen the time spent on pronunciation and to increase the time spent on teaching reading strategies and discussing the meaning of the text. The role of the teacher in modeling such strategies and in verbalizing thoughts could then be highlighted. Another important aspect in teacher training could be the role of the mother tongue in learning to read in a second language. The teachers discouraged speaking in the mother tongue, although the development of the first language may facilitate learning the second language [12].

When it comes to the available resources for reading comprehension instruction, the lack of materials leads to the students not having the opportunity to read texts by themselves. The students did not have the opportunity to spend time on actual reading different texts of different genres and to apply the reading strategies and skills they have learned. Although more (text) books are conditional for the students to be able to practice their reading comprehension skills, simply providing more books will not automatically help the students with weaker reading skills. Because not all students are able to read, providing more textbooks will not necessarily lead to an improvement of the reading comprehension skills of these students [27].

Future research could expand the results from the present study by examining the effects of teacher training when it comes to reading comprehension instruction. Also, future research could expand the present study by looking at the instruction of other subjects, as well as the instruction for other levels of schooling.

\section{CONCLUSION}

This study gives a detailed description of the way reading comprehension is taught in Sierra Leone and provides a starting point from which improvement in reading comprehension instruction could be established. Through observations, interviews and questionnaires a clear 
picture of reading comprehension practices in this developing country emerged. Reading comprehension lessons were characterized by a highly teacher-centered teaching style. This instruction focused mainly on pronunciation, learning new vocabularies and memorization and to a much lesser extent on reading strategies, such as summarizing and identification of the main idea of a text. The lessons were influenced by the limited availability of resources like textbooks, reading materials and school equipment.

\section{COMPETING INTERESTS}

Authors have declared that no competing interests exist.

\section{REFERENCES}

1. Rosling H. The good news of the decade? 2010. Accessed 26 February 2012. Available: http://www.ted.com/talks/hans rosling the good news of the decade.html

2. Harbison R, Hanushek EA. Educational performance of the poor: lessons from rural northeast Brazil. J Econ Lit. 1992;32(1):152-154.

3. World Bank. Education for all; 2009. Accessed 26 February 2012. Available: http://web.worldbank.org/WBSITE/EXTERNAL/TOPICS/EXTEDUCATION/0,,contentM DK:20374062 menuPK:540090 pagePK:148956 piPK:216618 theSitePK:282386,00 .html

4. Global Campaign for Education. EFA en Millenniumdoelen; 2012. Accessed 26 February 2012.

Available: http://www.globalcampagnforeducation.nl/efa-en-millenniumdoelen

5. Hanushek EA, Woessmann L. The role of school improvement in economic development; 2007. Accessed 26 February 2012.

Available: http://www.nber.org/papers/w12832

6. Unesco. EFA Global Monitoring Report. The quality imperative. Paris, France: Unesco; 2005.

7. National Reading Panel. Teaching children to read: an evidence-based assessment of the scientific research literature on reading and its implications for reading instruction; 2000. Accessed 10 March 2012.

Available: http://www.nationalreadingpanel.org/publications/subgroups.htm

8. Blair TR. Reading comprehension instruction. CamTESOL Conference on English Language Teaching: Selected Papers. 2008;4:132-137.

9. Slavin RE. What works? Issues in synthesizing program evaluations. Educ Res. 2008;37(1): 5-14.

10. Glewwe PW, Kremer M. Schools, teachers, and education outcomes in developing countries; 2005. Accessed 12 March 2012.

Available:http://www.givewell.orgfiles/DWDA\%202009/Interventions/EconEducationHa ndbook.pdf

11. Chaudhury N, Hammer J, Kremer M, Muralidharan K, Rogers FH. Missing in action: Teacher and health worker absence in developing countries. J Econ Perspect. 2006;20(1):91-116.

12. Cummins J. Bilingual children's mother tongue: Why is it important for education? Sprogforum. 2001;19:15-20.

13. Williams E. Extensive reading in Malawi: Inadequate implementation or inappropriate innovation? J Res Read. 2007;30(1):59-79.

14. Vavrus $F$. The cultural politics of constructivist pedagogies: teacher education reform in the United Republic of Tanzania. Int J Educ Dev. 2009;29:303-311. 
15. Tabulawa R. International aid agencies, learner-centered pedagogy and political democratization: A critique Comp Educ. 2003;39(1):7-26.

16. Croft A. Singing under a tree: Does oral culture help lower primary teachers be learnercentred? Int J Educ Dev. 2002;22:321-337.

17. Bisschop H. Quality of teachers in rural and urban areas of Sierra Leone. [master's thesis]. Amsterdam: University of Amsterdam; 2007.

18. Ware SA. Secondary school science in developing countries: Status and issues. PHREE Background Paper Series, 92/53. Washington DC: World Bank; 1992.

19. Richmond JED. Bringing critical thinking to the education of developing country professionals. Int Educ J. 2007;8(1);1-29.

20. World Bank. Education in Sierra Leone - present challenges, future opportunities. Washington DC: The World Bank; 2007.

21. Federal Ministry for Economic Cooperation and Development. Education in developing countries; 2010. Accessed 30 May 2012.

Available:http://www.bmz.de/en/what we do/issues/Education/hintergrund/bildungsitu ation/index.html

22. World Bank. From evidence to policy. Washington D.C: The World Bank; 2012.

23. Unesco Institute of Statistics. Education profile, Sierra Leone; 2013. Accessed 13 June, 2013.

Available:http://stats.uis.unesco.org/unesco/TableViewer/document.aspx?Reportld=12 $1 \&$ IF Language $=$ en\&BR Country $=6940$

24. Evangelical Fellowship of Sierra Leone. Member churches/organizations; 2009. Accessed 9 March 2012. Available: http://www.efsl.evang.org/about-efsl/members

25. Mullis IVS, Martin MO, Kennedy AM, Trong KL, Sainsbury M. PIRLS 2011, assessment framework. Boston: TIMSS \& PIRLS International Study Center; 2009.

26. Van Elsäcker W. Development of reading comprehension: The engagement perspective [dissertation]. Nijmegen: Radboud University. 2002;245.

27. Glewwe PW, Kremer M., Moulin S. Many children left behind? Textbooks and test scores in Kenya. Cambridge, Massachusetts: Center for International Development at Harvard University; 2007.

(c) 2014 Hersbach et al.; This is an Open Access article distributed under the terms of the Creative Commons Attribution License (http://creativecommons.org/licenses/by/3.0), which permits unrestricted use, distribution, and reproduction in any medium, provided the original work is properly cited.

Peer-review history:

The peer review history for this paper can be accessed here: http://www.sciencedomain.org/review-history.php?iid=484\&id=21\&aid=4261 